Наталія ЗАСЦь, orcid.org/0000-0002-5547-6714 аспірантка кафедри педагогіки, управління та спеціальної освіти Університету менеджменту освіти (Київ, Україна) natalia.zayets@ukr.net

\title{
СТРУКТУРНО-ФУНКЦІОНАЛЬНА МОДЕЛЬ ФОРМУВАННЯ ГОТОВНОСТІ ДО ПРОФЕСІЙНОЇ МОБІЛЬНОСТІ МАЙБУТНІХ КЕРІВНИКІВ ЗАКЛАДІВ ЗАГАЛЬНОЇ СЕРЕДНЬОЇ ОСВІТИ ЗА УМОВ МАГІСТРАТУРИ
}

\begin{abstract}
У статті схарактеризовано сутність понять «модель» $i$ «моделювання»; здійснено спробу запровадити структурно-функиіональну модель формування готовності до професійної мобільності майбутніх керівників закладів освіти за умов магістратури. Визначено, щчо меті дослідження найбільш відповідає структурно-функиіональна модель, яка графічно та детально відображає функиіональні особливості готовності до професійної мобільності. Запропонована модель позиціонується засобами теоретичного обгрунтування структурних компонентів досліджуваного явища. В обтрунтуванні моделі формування готовності до професійної мобільності майбутніх керівників закладів освіти враховано особливості майбутньої професійної діяльності й активну суб'єктну професійну позицію здобувачів вищої освіти. Модель розроблено на основі визначених теоретикометодологічних засад і представлено відповідними блоками: ичілепокладання, організаційно-змістовим і результативним. Зазначено, щзо до блоку иілепокладання включено мету, сутність якої полягає у формуванні готовності до професійної мобільності майбутніх керівників закладів загальної середньої освіти за умов магістратури, методологічні підходи та принципи як основу для виявлення та дослідження змістових компонентів готовності до професійної мобільності в освітньому процесі закладу вищої освіти. Організаційно-змістовий блок моделі включає прочесуальний аспект і періоди формування готовності до професійної мобільності (стійкий розвиток, суперечності, структурування (впорядкування), форми, методи, засоби навчання та відповідні організаційнопедагогічні умови). Результативний блок представлено за допомогою критерїв (мотиваційно-особистісного, когнітивно-діяльнісного та рефлексивного) з відповідними їм показниками та рівнями: креативним (високим), функиіональним (достатнім), інтуїтивним (середнім).

Ключові слова: модель, моделювання, структурно-функиіональна модель, професійна мобільність, структурно-функціональна модель готовності до професійної мобільності майбутніх керівників закладів загальної середньої освіти.
\end{abstract}

Natalia ZAYETS, orcid.org/0000-0002-5547-6714 Graduate Student at the Department of Pedagogy, Management and Special Education University of Educational Management (Kyiv,Ukraine)natalia.zayets@ukr.net

\section{STRUCTURAL-FUNCTIONAL MODEL OF READINESS FOR PROFESSIONAL MOBILITY OF FUTURE HEADS OF INSTITUTIONS OF GENERAL SECONDARY EDUCATION IN CONDITIONS}

In the article on the basis of the analysis of concepts "model", "modelling" the attempt is made to reproduce structuralfunctional model of formation of readiness for professional mobility of future heads of educational institutions in the conditions of a magistracy. It is determined that the purpose of the study best meets the structural-functional model, which graphically and in detail reflects the functional features of structural readiness for professional mobility. The proposed model is revealed through the description and theoretical substantiation of the structural components of the studied phenomenon. In the course of substantiation of the model of formation of readiness for professional mobility of future heads of educational institutions the peculiarities of future professional activity and active subjective professional position of applicants for higher education are taken into account. The model is developed on the basis of certain theoretical and methodological principles and is presented in the block of goal setting, organizational and semantic and effective blocks. It is noted that the goal-setting block includes the goal, the essence of which is to form readiness for professional mobility of future leaders of High Level School in the conditions of master's degree, methodological approaches and principles as a basis for identifying and researching semantic components of readiness for professional mobility in higher education. The organizational and semantic block of the model focuses on the selection of the procedural aspect and integrates the 
periods of formation of readiness for professional mobility (sustainable development, contradictions, structuring), forms, methods, teaching aids and relevant organizational and pedagogical conditions. mobility of future education managers is presented based on the criteria: (motivational-personal, cognitive-activity and reflexive) with the corresponding indicators and levels: creative (high), functional (sufficient), intuitive (medium).

Key words: model, modeling, structural-functional model, professional mobility, structural-functional model of readiness for professional mobility of future heads of general secondary education institutions.

Постановка проблеми. Обраний Україною шлях до європейської інтеграції та запроваджені карантинні обмеження, зумовлені пандемією, спонукають до інтенсивних змін у підходах до управління закладами загальної середньої освіти (далі - 33СО). 3 огляду на це логічною та науково обгрунтованою постає потреба в підготовці нової генерації менеджерів освіти, готових і здатних до реалізації стратегічних освітніх завдань за умов суспільних змін.

Сьогодні вагомим чинником успішного функціонування 3ЗСО й умовою ефективного використання кращого управлінського досвіду $\epsilon$ формування готовності до професійної мобільності майбутніх керівників закладів освіти за умов магістратури.

Зауважимо, що професійна мобільність фахівця розглядається як оптимальний стиль його діяльності у процесі професійного самовизначення та професійної самореалізації в контексті соціальноекономічної ситуації. Відповідно, готовність до професійної мобільності є якістю особистості, яка забезпечує оптимальний стиль іiі діяльності у процесі професійного самовизначення та професійної самореалізації за соціально-економічних умов сучасного суспільства, що постійно змінюються (Нужнова, 2004).

Одним із дієвих шляхів формування готовності до професійної мобільності майбутніх керівників закладів освіти вважаємо використання методу моделювання як універсального методу пізнання, що дозволить нам створити модель і намітити пріоритетні напрями у становленні особистості майбутніх керівників 33СО у закладах вищої освіти.

Аналіз досліджень. Теоретичні та практичні аспекти формування готовності до професійної мобільності відображені в дослідженнях Л. Герасимової, Ю. Калиновського, Б. Львова, С. Нужнової, Р. Пріми, Л. Сушенцевої. Серед вітчизняних питанню управління освітою присвячені праці Т. Гриценко, Л. Даниленко, 3. Рябової, Г. Тимошко, Т. Сорочан та ін. Проблему педагогічного моделювання висвітлювали О. Боднар, О. Дахін, Г. Сльникова, В. Маслов, В. Пікельна, В. Штофф та інші науковці.

Мета статті полягає в обгрунтуванні структурно-функціональної моделі формування готовності до професійної мобільності майбутніх керівників $33 \mathrm{CO}$ за умов магістратури.
Виклад основного матеріалу. У сучасних наукових джерелах «моделювання» трактується як робочий інструмент, що дозволяє прогнозувати і програвати можливості та наслідки різних варіантів нововведень, а також чітко спроектувати внутрішню структуру об'єкта або процесу, сукупність діючих чинників і на підставі виявлених тенденцій розвитку екстраполювати їх у майбутню професійну діяльність (Г. Коджаспіров, О. Мармаза, В. Маслов).

Моделювання як один із провідних методів наукового дослідження широко застосовується у сучасних науково-педагогічних дослідженнях. Цей метод покликаний поєднати педагогічний об'єкт і експеримент із побудовою логічних конструкцій і наукових припущень. В. Маслов вважає моделювання не тільки методом, а й підсистемою (самостійною стадією) управління, яка має специфічні функції та форми прояву (Маслов, 2009).

С. Гончаренко зазначає, що сутність моделювання полягає у встановленні подібності явищ (аналогій), адекватності одного об'єкта іншому в певних відношеннях і на цій основі перетворення простішого за структурою і змістом об'єкта в модель складнішого (оригінал). На думку науковця, механізм моделювання складається із таких операцій, як: перехід від природного об'єкта до моделі, побудова моделі; експериментальне дослідження моделі; перехід від моделі до природного об'єкта, який полягає в перенесенні результатів, одержаних у дослідженні, на певний предмет (Гончаренко, 2010).

Одним із дієвих засобів поліпшення якості процесу формування готовності до професійної мобільності майбутніх керівників $33 \mathrm{CO}$ за умов магістерської підготовки є побудова його моделі.

Поняття «модель» (від франц. modele - міра, зразок, норма; латинськ. - образ, зменшений варіант, спрощений опис складного явища чи процесу) розуміється уявною чи матеріально реалізованою системою, яка відображає об'єкт дослідження і здатна змінювати цей об'єкт так, що ознайомлення з нею надає нові дані про окреслений об'єкт (Кремень, 2008).

На думку Г. Тимошко, модель має декілька застосувань: насамперед вона дозволяе чітко визначити компоненти, які складають систему, досить точно і схематично подати зв'язки між 
компонентами; зв'язки всередині модельованого об'єкта можна порівняти зі зв'язками всередині моделі. Модель генерує та породжує питання, стає інструментом для порівняльного вивчення різних галузей явища або процесу (Тимошко, 2014: 483).

Нам імпонує визначення моделі, надане В. Штоффом: «Модель - це подумки уявлена або матеріально реалізована система, котра, відбиваючи або відтворюючи об'єкт дослідження, здатна його заміщати так, що ії вивчення дасть нам нову інформацію про цей об'єкт» (Штоф, 1966: 19).

Моделювання процесу підготовки фахівців за умов ЗВО використовується в педагогічній науці як метод навчання та метод наукового пошуку. Застосовуються різні класифікації моделей, структурованих за певними ознаками та принципами побудови:

- матеріальні (статичні й динамічні) та ідеальні (образні, знакові й уявні) моделі (К. Гнеєзділова);

- матеріальні та ідеальні моделі (В. Штоф);

- технократичні та гуманістичні моделі (І. Зязюн);

- регресійні,теоретико-ймовірнісні,теоретикоінформаційні, структурні, функціонально-системні, структурно-алгоритмічні та ін.

Неодмінною рисою моделей, як зауважує Г. Єльнікова, є володіння певною структурою. Основна вимога до моделей - можливість використання для вивчення або перетворення реального світу (Сльнікова, 2010).

Ми погоджуємося 3 думкою В. Івлєва, що моделі формування професійної мобільності або iї видів $\epsilon$ структурно-функціональними й умовно можуть бути віднесені до інституційних (блочних). У структурі такої моделі зазвичай виділяють: мету (завдання); компетентності / компоненти - компетенції, якості особистості і т. п.; форми / методи / засоби / принципи, які використовуються для формування професійної мобільності; критерії / рівні сформованості професійної мобільності; педагогічні (організаційно-педагогічні умови), результат формування мобільності тощо (Івлєв, 2019: 125).

3 огляду на схарактеризовані науковцями положення щодо створення моделей, зокрема щодо формування професійної мобільності фахівців, беручи до уваги процес модернізації сучасної вищої освіти, враховуючи функціональні обов'язки майбутніх керівників i значущість у структурі їхньої діяльності процесу формування професійної мобільності, ми переконалися в доцільності створення структурно-функиіональної моделі готовності до професійної мобільності майбутніх керівників $33 С О$ за умов магістратури.
Під структурно-функціональною моделлю будемо розуміти модель, яка графічно детально відображає функціональні особливості структурних елементів досліджуваного нами явища.

У свою чергу, опираючись на дослідження В. Маслова, В. Івлєва, Т. Рожнової, Н. Клокар та інших науковців, ми представили авторське визначення структурно-функиіональної моделі формування готовності до професійної мобільності майбутніх керівників 33СО, щзо передбачає иілісний педагогічний прочес, у якому використання єдності та взаємоінтеграції методів, приниипів, підходів $і$ компонентів навчання спрямовані на набуття студентами визначених компетенцій, що вказують на їхній особистісний розвиток як майбутніх професіоналів-управлінців.

Змістові та методичні пріоритети процесу формування готовності до професійної мобільності майбутніх керівників $33 \mathrm{CO}$ детерміновані особливостями майбутньої професійної діяльності: основний акцент зроблено на активній суб'єктній професійній позиції здобувача вищої освіти. Виокремлення структурних компонентів моделі свідчить про її гнучкість, адаптивність і взаємодію, що є ознакою системи внутрішньої організації процесу формування готовності до професійної мобільності майбутніх менеджерів освіти та дозволяє розподілити їі на окремі блоки: цілепокладання, організачійно-змістовий, результативний, які зумовлюють можливість відстеження цілеспрямованої динаміки процесу формування готовності до професійної мобільності майбутніх керівників 33СО за умов магістратури.

Блок цілепокладання структурно-функціональної моделі включає мету, сутність якої полягає у формуванні готовності до професійної мобільності майбутніх керівників 33СО за умов магістратури, методологічні підходи та принципи, які $\epsilon$ підгрунтям досліджуваного явища й основою для виявлення та дослідження змістових компонентів в освітньому процесі закладу вищої освіти.

Розроблена модель розглядається нами з позиції методологічних підходів: акмеологічного, системного, андрагогічного, синергетичного, аксіологічного, особистісно-діяльнісного, компетентісного, на основі яких обгрунтовано компоненти змісту готовності до професійної мобільності майбутніх керівників 33СО (мотиваційно-аксіологічний, когнітивно-діяльнісний, особистісно-рефлексивний).

Процес формування готовності до професійної мобільності майбутніх керівників 33СО здійснюється на засадах принципів, які виконують регулятивну функцію і розглядаються як висхідні умови до організації педагогічного процесу на практичному рівні (Яковлева, 2002). 
У контексті розроблення моделі формування готовності до професійної мобільності майбутніх керівників 33СО було обгрунтовано спектр ключових принципів:

- методологічних: єдності аналізу і синтезу, об'єктивності, системності, зворотного зв'язку, прогностичності, інтеграції, диференціації, професійної належності, взаємодії особистісного та професійного розвитку та ін.;

- специффічних (особливих): гуманізації; оптимального співвідношення індивідуального, особистісного і професійного розвитку; суб'єктної орієнтації; контекстності, безперервності, рефлексивності.

Реалізація зазначених принципів передбачає диференціацію й інтеграцію змісту освітнього процесу i його зосередженість на формуванні готовності майбутніх керівників 33СО до професійної мобільності.

3 огляду на те, що формування готовності до професійної мобільності майбутніх керівників З3СО здійснюється під системним цілісним впливом всіх компонентів освітнього процесу, в організаційно-змістовому блоці моделі увагу було акцентовано на виділенні процесуального аспекту досліджуваного явища. До цього блоку ми включили періоди формування готовності до професійної мобільності, форми, методи та засоби навчання, що сприяють формуванню готовності до професійної мобільності майбутніх фахівцівуправлінців для 33СО, та відповідні їм організаційно-педагогічні умови. Деталізуємо окремі складники зазначеного блоку.

Успішне й ефективне формування готовності до професійної мобільності майбутньої управлінської еліти забезпечується певними організаційно-педагогічними умовами, під якими розуміємо навмисно створену чи природну, оптимальну i достатню сукупність зовнішніх чи внутрішніх чинників та інструментів, щозабезпечують ефективність функціонування педагогічної системи у напрямі формування готовності до професійноі мобільності майбутніх керівників закладів освіти.

Розв'язання наших дослідницьких завдань залежить від таких організаційно-педагогічних умов, як:

- спрямованість освітнього процесу ЗВО у формуванні готовності до професійної мобільності майбутніх керівників 33СО на формування визначених компетенцій;

- використання інноваційних та інтерактивних педагогічних технологій в освітньому процесі закладу вищої освіти, спрямованих на формування готовності до професійної мобільності майбутніх керівників 33СО;
- науково-методичний супровід процесу формування готовності до професійної мобільності майбутніх керівників $33 \mathrm{CO}$ за умов магістратури.

Формами реалізації запропонованої нами моделі, на наш погляд, є: проблемні лекції; семінари, дискусії; робота в парах, у групах; індивідуальні заняття; консультації; самостійна навчальнопізнавальна діяльність (індивідуальні навчальні завдання, проекти, курсові роботи); тренінги; професійні проби, майстер-класи, творчі зустрічі, навчально-виробнича практика та ін.

Як дієвий засіб навчання в моделі ми пропонуємо доповнення змісту базових дисциплін у підготовці фахівців спеціалізації «Управління навчальним закладом» теоретико-практичними блоками із проблеми формування готовності до професійної мобільності шляхом впровадження авторського інтегрованого спецкурсу «Основи професійної мобільності майбутніх керівників 33СО», дидактичною метою якого $є$ надання освітньому процесу ЗВО цілісності, системності, інноваційності.

Для реалізації форм навчання нашої моделі доцільним є використання методів, спрямованих на саморозвиток, самовдосконалення, формування відповідних компетенцій, що визначають професійну мобільність. Вибір методів відіграє важливу роль в організації цікавого навчального процесу за допомогою забезпечення позитивної групової динаміки та сприяння навчанню студентів. Серед таких методів ми виокремили традиційні та інноваційні: активні, інтерактивні (імітаційні, не імітаційні) та ін.

Процес формування готовності до професійної мобільності майбутніх керівників $33 \mathrm{CO}$ за умов магістратури ми умовно розподілили на три взаємопов'язані періоди: стійкий розвиток (1 курс), суперечності (2 курс), структурування (впорядкування) (останнє півріччя 2 курсу).

Для першого періоду характерним є стійкий розвиток, під час якого відбувається складна цілеспрямована, запрограмована діяльність. Другий період визначається суперечностями між усталеними відносинами та соціально-економічними змінами в суспільстві, що приводить до появи різних інновацій в освітній системі, накопичення новітніх способів розв'язання проблем, пов'язаних із підготовкою професійно мобільних фахівців. Система перебуває у стані постійного пошуку сприятливого для нових умов режиму функціонування. Третій період - структурування, упорядкування, початок стійкого розвитку (зменшується розмаїття форм і методів, виникають стійкі форми нових відносин між суб'єктами освітнього процесу, проходить набір оптимальних засобів функціонування системи). У самій 
системі проходить визначення цілей розвитку, саморозвитку. У цей період може виникає зворотний зв'язок: повернення до почасового періоду означає досягнення певної межі впорядкованості (Заєць, 2017: 66).

Результативний блок моделі розкриває уявлення про результат формування готовності до професійної мобільності майбутніх менеджерів освіти, опираючись на критерії (мотиваційно-особистісний, когнітивно-діяльнісний і рефлексивний) із відповідними показниками та рівнями: креативним (високим), функиіональним (достатнім), інтуїтивним (середнім) у формуванні цієї інтегративної якості.

Практична спрямованість моделі готовності до професійної мобільності майбутніх керівників З3СО за умов магістерської підготовки є вагомим чинником підготовки до динамічних професійних буднів; переконує магістранта у його сформованих перевагах $\mathrm{i}$ допомагає визначити недоліки можливого професійного майбуття, перетворюючи власний досвід у постійний розвиток, підвищення кваліфікаційного рівня, об'єктивну оцінку можливостей кар'єрного зростання і запланованих звершень і досягнень; забезпечує освоєння нововведень і готовність до невизначеності, аналітичності, прогностичності.

Резюмуючи, зазначимо, що у змісті структурно-функціональної моделі закладено достатній ресурс для формування готовності до професійної мобільності майбутніх керівників 33СО.
Така модель дозволяє комплексно дослідити аналізований процес, системно охопити його основні напрями, етапи, функції та компоненти, тим самим забезпечуючи успішне формування готовності до професійної мобільності. Однак успішна реалізація педагогічного процесу закладу вищої освіти визначається не лише змістом, але й процесуальним аспектом у вигляді цілеспрямованої взаємодії викладачів і студентів на шляху до реалізації визначених цілей.

Висновки. Розроблена нами структурно-функціональна модель не претендує на досконалість. Нами лише було окреслено найбільш значущі та необхідні, на наш погляд, умови, механізми та інструменти для успішного формування готовності до професійної мобільності майбутніх керівників 33СО за умов закладу вищої освіти. Ця модель може бути доповнена й адаптована відповідно до особливостей та умов освітнього процесу конкретного закладу вищої освіти. Водночас, на наше переконання, окреслені в цій публікації базові принципи формування готовності до професійної мобільності майбутньої управлінської освітньої еліти сприятимуть їх професійному й особистісному зростанню за сучасних динамічних умов.

Перспективи подальших розвідок в обраному напрямі вбачаємо в експериментальній перевірці моделі, спрямованої на удосконалення процесу формування готовності до професійної мобільності майбутніх керівників 33СО за умов магістратури.

\section{СПИСОК ВИКОРИСТАНИХ ДЖЕРЕЛ}

1. Великий тлумачний словник сучасної української мови / за ред. В. Т. Бусел. Київ - Ірпінь : ВТФ «Перун». 2001. $1440 \mathrm{c}$.

2. Гончаренко С. У. Педагогічні дослідження: Методологічні поради молодим науковцям. Київ - Вінниця: ТОВ фірма «Планер». 2010. 308 с.

3. Заєць Н. Ю. Готовність до професійної мобільності фахівців - відповідь на виклики часу. Вісник Черкаського університету. № 17-18. Серія Педагогічні науки. 2017. С. 60-68.

4. Єльникова Г. В. Компетентісний підхід до моделювання професійної діяльності керівника вищого навчального закладу. Теорія та методика управління освітою. 2010. № 4. URL: http://tme. umo.edu.ua.

5. Ієвлєв О. М. Модель формування професійно-педагогічної мобільності майбутнього викладача за умов магістратури. Інноваційна педагогіка. 2019. Вип. 12. Т. 2. С. 123-127.

6. Кремень В. Г. Ковбасюк Ю. В. Освіта дорослих : енциклопедичний словник / Нац. акад. пед. наук України, Нац. акад. держ. упр. при Президентові України. Київ : Основа, 2014. 496 с.

7. Маслов В. І Концептуальні засади побудови, зміст і структура орієнтовної моделі функціональної компетентності керівників навчальних закладів. Післядипломна освіта в Україні. 2009. № 2 (15). С. 3-10.

8. Нужнова С. В. Сущность и структура понятия профессиональной мобильности в современном обществе. Москва, 2004. 258 с.

9. Тимошко Г. М. Організаційна культура керівника загальноосвітнього навчального закладу: теорія і практика : монографія. Ніжин : Видавець ПП Лисенко М. М. 2014. 592 с.

10. Штофф В.А. Моделирование и философия. Ленинград : Наука, 1966. 302 с.

11. Яковлева Н. О. Концепция педагогического проектирования: методологические аспекты : монография. Москва : Информационно издательский центр АТиСО, 2002. 194 с. 


\section{REFERENCES}

1. Velykyi tlumachnyi slovnyk suchasnoi ukrainskoi movy (2009) [Large explanatory dictionary of the modern Ukrainian language] / uklad. i holov. red. V. T. Busel. Kyiv; Irpin: VTF Perun, 2009. 1736 s. [in Ukrainian].

2. Honcharenko S. U. Pedahohichni doslidzhennia: Metodolohichni porady molodym naukovtsiam. [Pedagogical research: Methodological advice for young scientists]: Kyiv - Vinnytsia: TOV firma "Planer". 2010. 308 s. [in Ukrainian].

3. Zaiets N. Iu. Hotovnist do profesiinoi mobilnosti fakhivtsiv - vidpovid na vyklyky chasu. [Readiness for professional mobility of specialists is a response to the challenges of time]: Visnyk Cherkaskoho universytetu. № 17-18. Seriia Pedahohichni nauky. 2017. S. 60-68. [in Ukrainian].

4. Ielnykova H. V. Kompetentnisnyi pidkhid do modeliuvannia profesiinoi diialnosti kerivnyka vyshchoho navchalnoho zakladu. [Competent approach to modeling the professional activity of the head of a higher education institution]: Teoriia ta metodyka upravlinnia osvitoiu. 2010. № 4. URL: http://tme. umo.edu.ua. [in Ukrainian].

5. Iievliev O. M. Model formuvannia profesiino-pedahohichnoi mobilnosti maibutnoho vykladacha v umovakh mahistratury. [Model of formation of professional and pedagogical mobility of the future teacher in the conditions of a magistracy]: Innovatsiina pedahohika. 2019, Vyp. 12, t. 2. S. 123-127. [in Ukrainian].

6. Kremen V.H. Kovbasiuk, Yu.V. Osvita doroslykh: entsyklopedychnyi slovnyk. [Adult education: an encyclopedic dictionary]: Nats. akad. ped. nauk Ukrainy, Nats. akad. derzh. upr. pry Prezydentovi Ukrainy. Kyiv: Osnova. 2014.496 s. [in Ukrainian].

7. Maslov V. I Kontseptualni zasady pobudovy, zmist i struktura oriientovnoi modeli funktsionalnoi kompetentnosti kerivnykiv navchalnykh zakladiv. [Conceptual principles of construction, content and structure of the approximate model of functional competence of heads of educational institutions]: Pisliadyplomna osvita v Ukraini. 2009. № 2 (15). S. 3-10. [in Ukrainian].

8. Nuzhnova S. V. Suschnost i struktura ponyatiya professionalnoy mobilnosti v sovremennom obschestve. [The essence and structure of the concept of professional mobility in modern society]: Moskva, 2004. $258 \mathrm{~s}$. [in Russian].

9. Tymoshko H. M. Orhanizatsiina kultura kerivnyka zahalnoosvitnoho navchalnoho zakladu: teoriia i praktyka: [Organizational culture of the head of a secondary school: theory and practice]: Monohrafiia. Nizhyn: Vydavets PP Lysenko M. M. 2014. 592 s. [in Ukrainian].

10. Shtoff V. A. Modelirovanie i filosofiya. [Modeling and philosophy]: Leningrad: Nauka, 1966. 302 s. [in Russian].

11. Yakovleva N. O. Kontseptsiya pedagogicheskogo proektirovaniya: metodologicheskie aspektyi: [The concept of pedagogical design: methodological aspects]: Mon ografiya. Moskva: Informatsionno izdatelskiy tsentr ATiSO, 2002. 194 s. [in Russian]. 